\title{
Bedsore revitalization by- LLLT, low level laser (LED- Ga-Al- As 660) therapy
}

\section{Keywords}

bedsore healing, soft tissue healing, decubitus ulcer healing, low level laser; wound healing

\section{Background}

In 1967 a few years after the first working laser was invented, Endre Mester in Semmelweis University Budapest, Hungary wanted to find out if laser might cause cancer. He took some mice, shaved the hair off their backs, divided them into two groups and gave a laser treatment with a low powered ruby laser to one group. They did not get cancer and to his surprise the hair on the treated group grew back more quickly than the untreated group. That was how "laser biostimulation" was discovered.

\section{Purpose of the work}

The effects of pulsed monochromatic light, with fixed pulsations and wavelengths, on the healing of pressure ulcers were evaluated in this prospective, randomized, controlled study.

\section{Approach and methodology}

A placebo-controlled, double-blind study using low energy photon therapy (LLLT) was performed in ten patients with bedsore on the
Volume 5 Issue I - 2017

\section{Mohammad Nazrul Islam, Golam Abu Zakaria, kazi Shamimuzzaman, Quamrul Akhter Sanju \\ Shaheed Suhrawardy Medical College Hospital, Bangladesh}

Correspondence: Mohammad Nazrul Islam, Head - Biomedical and Medical Biotechnology Dept. Shaheed Suhrawardy Medical College Hospital. Dhaka- I207, Bangladesh, Tel CELL: +88-01733381819; Email abbirr@gmail.com; abbirr@yahoo.com

Received: October 16, 2016 | Published: January 27, 2017

back. Treatment was given three times a week for 10 weeks, using monochromatic (red) optical sources; diode 660nm (GaAl-660). The patients who were randomized to placebo treatment received sham therapy from an identical-appearing light source from the same delivery system.

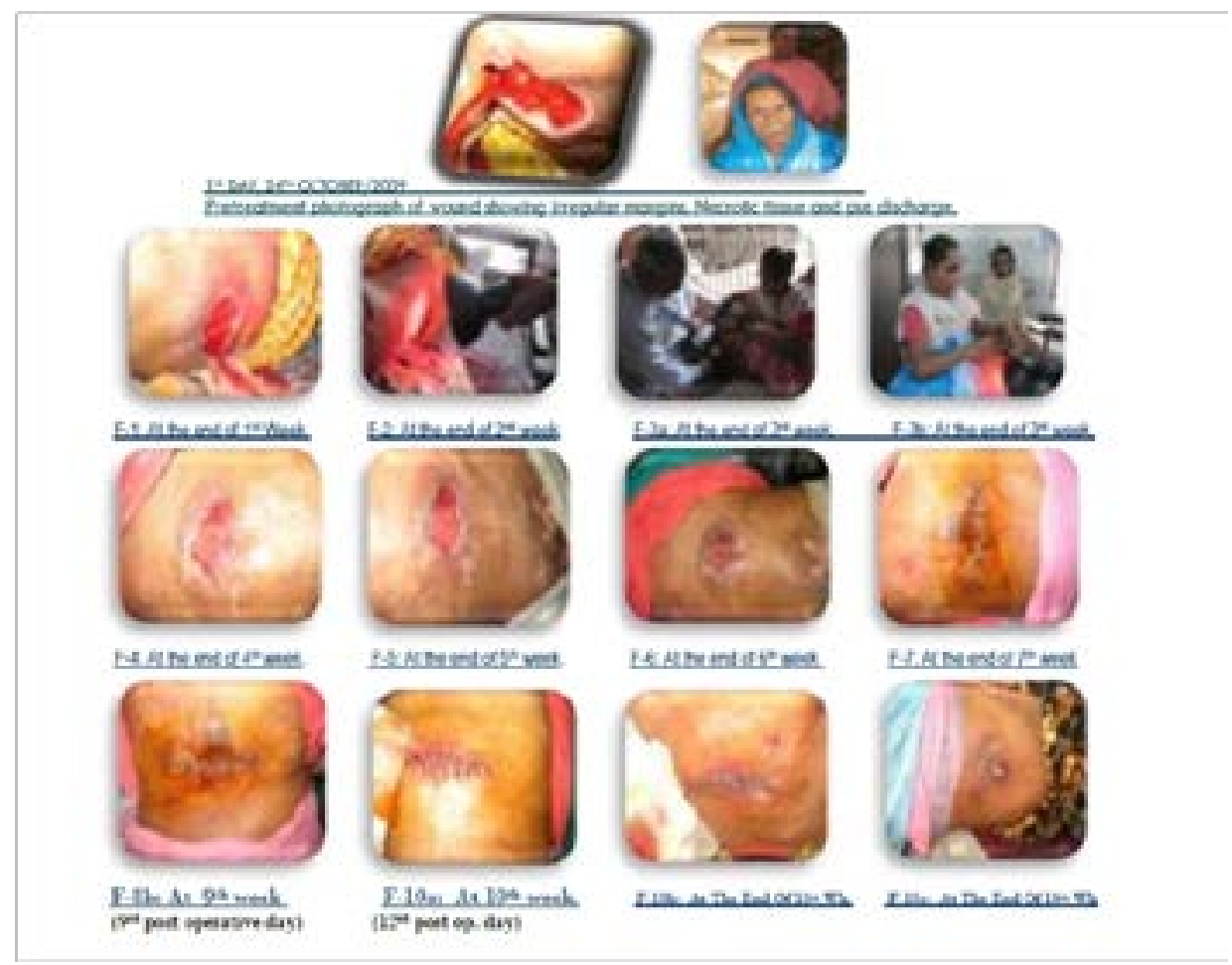

Figure I Chronological picture view of a laser (LLLT) treated patient. 


\section{Results}

Ten patients with 10 bedsore were randomized to receive LLLT or placebo therapy. At the conclusion of the study, the percentage of the initial ulcer area remaining unhealed in the LLLT and placebo groups was $24.4 \%$ and $84.7 \%$, respectively $(\mathrm{P}=0.0008)$. The decrease in ulcer area (compared to baseline) observed in the LLLT and placebo groups was $193.0 \mathrm{~mm}^{2}$ and $14.7 \mathrm{~mm}^{2}$, respectively $(\mathrm{P}=0.0002)$.

One patient dropped out of the study, complaining of lack of treatment efficacy; he was found to be randomized to the placebo group. There were no adverse effects.

\section{Conclusion}

In this placebo-controlled, double-blind study LLLT was an effective modality for the treatment of bedsore which were resistant to conventional medical management.

The results are encouraging as pulsed monochromatic light increased healing rate and shortened healing time. This will positively affect the quality of life in elderly patients with pressure ulcers. ${ }^{1-57}$

\section{Acknowledgement}

None.

\section{Conflict of interest}

None.

\section{References}

1. Hamblin MR, Demidova TN. Mechanisms of Low Level Laser Therapy. Harvard Medical School. 2006;6140.

2. Pereira AN, Eduardo Cde P, Matson E, et al. Effect of low-power laser irradiation on cell growth and procollagen synthesis of cultured fibroblasts. Lasers Surg Med. 2002;31(4):263-267.

3. Sutherland JC. Biological effects of polychromatic light. Photochem Photobiol. 2002;76(2):164-170.

4. Karu T. Laser biostimulation: a photobiological phenomenon. J Photochem Photobiol B. 1989);3(4):638-640.

5. Karu TI, Afanaseva NI. Cytochrome c oxidase as the primary photoacceptor upon laser exposure of cultured cells to visible and near IR-range light. Dokl Akad Nauk. 1995;342(5):693-695.

6. Capaldi R A, Malatesta F, Darley Usmar V M. Structure of cytochrome c oxidase. Biochim Biophys Acta. 1983;726:135-148.

7. Szundi I, Liao GL, Einarsdottir O. Near-infrared time-resolved optical absorption studies of the reaction of fully reduced cytochrome $\mathrm{c}$ oxidase with dioxygen. Biochemistry. 2001;40(8):2332-2339.

8. Karu TI, Kolyakov SF. Exact action spectra for cellular responses relevant to phototherapy. Photomed Laser Surg. 2005;23(4):355-361.

9. Yu W, Naim JO, McGowan M, et al. Photomodulation of oxidative metabolism and electron chain enzymes in rat liver mitochondria. Photochem Photobiol. 1997;66(6):866-871.

10. Passarella S. He-Ne laser irradiation of isolated mitochondria. $J$ Photochem Photobiol B. 1989;3(4):642-643.

11. Friedmann H, Lubart R, Laulicht I, et al. A possible explanation of laserinduced stimulation and damage of cell cultures. J Photochem Photobiol B. 1991;11(1):87-91.
12. Eichler M, Lavi R, Shainberg A, et al. Flavins are source of visible-lightinduced free radical formation in cells. Lasers Surg Med. 2005;37(4):314 319.

13. Plaetzer K, Kiesslich T, Krammer B, et al. Characterization of the cell death modes and the associated changes in cellular energy supply in response to AlPcS4-PDT. Photochem Photobiol Sci. 2002;1(3):172-177.

14. Lubart R, Eichler M, Lavi R, et al. Low-energy laser irradiation promotes cellular redox activity. Photomed Laser Surg. 2005;23(1):3-9.

15. Duan R, Liu TC, Li Y, et al. Signal transduction pathways involved in low intensity $\mathrm{He}-\mathrm{Ne}$ laser-induced respiratory burst in bovine neutrophils: a potential mechanism of low intensity laser biostimulation. Lasers Surg Med. 2001;29(2):174-178.

16. Antunes F, Boveris A, Cadenas E. On the mechanism and biology of cytochrome oxidase inhibition by nitric oxide. Proc Natl Acad Sci USA. 2004;101(48):16774-16779.

17. Karu TI, Pyatibrat LV, Afanasyeva NI. Cellular effects of low power laser therapy can be mediated by nitric oxide. Lasers Surg Med. 2005;36(4):307-314.

18. Moriyama Y, Moriyama EH, Blackmore K, et al. In Vivo Study of the Inflammatory Modulating Effects of Low-level Laser Therapy on iNOS Expression Using Bioluminescence Imaging. Photochem Photobiol. 2005;81(6):1351-1355.

19. Schafer FQ, Buettner GR. Redox environment of the cell as viewed through the redox state of the glutathione disulfide/glutathione couple. Free Radic Biol Med. 2001;30(11):1191-1212.

20. Liu H, Colavitti R, Rovira II, et al. Redox-dependent transcriptional regulation. Circ Res. 2005;97(10):967-974.

21. Yang M, Nazhat N B, Jiang X, et al. Adriamycin stimulates proliferation of human lymphoblastic leukaemic cells via a mechanism of hydrogen peroxide (H2O2) production. Br J Haematol. 199695(2):339-344.

22. Kirlin WG, Cai J, Thompson SA, et al. Glutathione redox potential in response to differentiation and enzyme inducers. Free Radic Biol Med. 1999;27(11-12):1208-1218.

23. Alaluf S, Muir Howie H, Hu HL, et al. Atmospheric oxygen accelerates the induction of a post-mitotic phenotype in human dermal fibroblasts: the key protective role of glutathione. Differentiation. 2000;66(2-3):147-155.

24. Karu T. Primary and secondary mechanisms of action of visible to near-IR radiation on cells. J Photochem Photobiol B. 1999;49(1):1-17.

25. Young S, Bolton P, Dyson M, et al. Macrophage responsiveness to light therapy. Lasers Surg Med. 1989;9(5):497-505.

26. Fujimaki Y, Shimoyama T, Liu Q, et al. Low-level laser irradiation attenuates production of enactive oxygen species by human neutrophils. $J$ Clin Laser Med Surg. 2003;21(3):165-170.

27. Chen YS, Hsu SF, Chiu CW, et al. Effect of low-power pulsed laser on peripheral nerve regeneration in rats. Microsurgery. 2005;25(1):83-89.

28. Miloro M, Halkias LK, Mallery S, et al. Low-level laser effect on neural regeneration in Gore-Tex tubes. Oral Surg Oral Med Oral Pathol Oral Radiol Endod. 2002;93(1):27-34.

29. Balaban P, Esenaliev R, Karu T, et al. He-Ne laser irradiation of single identified neurons. Lasers Surg Med. 1992;12(3):329-337.

30. Byrnes KR, Waynant RW, Ilev IK, et al. Light promotes regeneration and functional recovery and alters the immune response after spinal cord injury. Lasers Surg Med. 2005;36(3):171-185.

31. Sayed SO, Dyson M. Effect of laser pulse repetition rate and pulse duration on mast cell number and degranulation. Lasers Surg Med. 1996;19(4):433-437. 
32. Lopes-Martins RA, Albertini R, Martins PS, et al. Spontaneous effects of low-level laser therapy $(650 \mathrm{~nm})$ in acute inflammatory mouse pleurisy induced by Carrageenan. Photomed Laser Surg. 2005;23(4):377-381.

33. Agaiby AD, Ghali LR, Wilson R, et al. Laser modulation of angiogenic factor production by T-lymphocytes. Lasers Surg Med. 2000;26(4): 357363.

34. Passarella S, Casamassima E, Molinari S, et al. Increase of proton electrochemical potential and ATP synthesis in rat liver mitochondria irradiated in vitro by helium-neon laser. FEBS Lett. 1984;175(1):95-99.

35. Greco M, Guida G, Perlino E, et al. Increase in RNA and protein synthesis by mitochondria irradiated with helium-neon laser. Biochem Biophys Res Commun. 1989;163(3):1428-1434.

36. Pastore D, Greco M, Petragallo VA, et al. Increase in $<-\mathrm{H}+/ \mathrm{e}-$ ratio of the cytochrome $\mathrm{c}$ oxidase reaction in mitochondria irradiated with heliumneon laser. Biochem Mol Biol Int. 1994;34(4):817-826.

37. Zhang Y, Song S, Fong CC, et al. CDNA microarray analysis of gene expression profiles in human fibroblast cells irradiated with red light. $J$ Invest Dermatol. 120(5):849-857.

38. Lyons RF, Abergel RP, White RA, et al. Biostimulation of wound healing in vivo by a helium-neon laser. Ann Plast Surg . 1987;18(1):47-50.

39. Yu HS, Chang KL, Yu CL, et al. Low-energy helium-neon laser irradiation stimulates interleukin-1 alpha and interleukin-8 release from cultured human keratinocytes. J Invest Dermatol. 1996;107(4):593-596.

40. Poon VK, Huang L, Burd A. Biostimulation of dermal fibroblast by sublethal Q-switched Nd: YAG $532 \mathrm{~nm}$ laser: collagen remodeling and pigmentation. J Photochem Photobiol B. 2005;81(1):1-8.

41. Kipshidze N, Nikolaychik V, Keelan MH, et al. Low-power helium: neon laser irradiation enhances production of vascular endothelial growth factor and promotes growth of endothelial cells in vitro. Lasers Surg Med. 2001;28(4):355-364.

42. Khanna A, Shankar LR, Keelan MH, et al. Augmentation of the expression of proangiogenic genes in cardiomyocytes with low dose laser irradiation in vitro. Cardiovasc Radiat Med. 1999;1(3):265-269.

43. Medrado AR, Pugliese LS, Reis SR, et al. Influence of low level laser therapy on wound healing and its biological action upon myofibroblasts, Lasers Surg Med. 2003;32(3):239-244.

44. Neiburger EJ. Rapid healing of gingival incisions by the helium-neon diode laser. J Mass Dent Soc. 1999;48(1):8-13.

45. Branco K, Naeser MA . Carpal tunnel syndrome: clinical outcome after low-level laser acupuncture, microamps transcutaneous electrical nerve stimulation, and other alternative therapies - an open protocol study. $J$ Altern Complement Med. 1999;5(1):5-26.
46. Irvine J, Chong SL, Amirjani N, et al. Double-blind randomized controlled trial of low-level laser therapy in carpal tunnel syndrome. Muscle Nerve. 2004;30(2):182-187.

47. Weintraub MI. Noninvasive laser neurolysis in carpal tunnel syndrome. Muscle Nerve. 1997;20(8):1029-1031.

48. Schindler A. Increased dermal neovascularization after low dose laser therapy. $2^{\text {nd }}$ Congress, World Association for Laser Therapy. Kansas City. 1998.

49. Almeida-Lopes L. Comparison of the low level laser therapy effects on cultured human gingival fibroblasts proliferation using different irradiance and same fluence. Lasers in Surgery and Medicine. 2001;29(2):179-184.

50. Samoilova KA, Boqacheva ON, Obolenskaya KD, et al. Enhancement of the blood growth promoting activity after exposure of volunteers to visible and infrared polarized light. Part I: stimulation of human keratinocyte proliferation in vitro. Advance Article of 2004 Photochemical \& Photobiological Sciences. 2004.

51. Barber A Luger JE, Karpf A, Salame Kh, et al. Advances in laser therapy for bone repair. The Journal of Laser Therapy 13. 2000.

52. Antonio L. Biomodulatory effects of LLLT on bone regeneration. The Journal of Laser Therapy. 2000;13.

53. Shefer G, Partridge TA, Heslop L, et al. Low energy laser irradiation promotes the survival and cell cycle entry of skeletal muscle satellite cells. Journal of Cell Science. 2002;115(7):1461-1469.

54. Enwemeka CS, Reddy GK, The biological effects of laser therapy and other modalities on connective tissue repair processes. The Journal of Laser Therapy 12. 2000

55. Reddy GK, Stehno-Bittel L, and Enwemeka CS. Laser photo stimulation accelerates wound healing in diabetic rats. Wound Repair and Regeneration. 2001;9(3):248-255.

56. Stadler I, Lanzafame RJ, Evans R, et al. $830 \mathrm{~nm}$ irradiation increases the wound tensile strength in diabetic murine model. Lasers in Surgery and Medicine. 2001;28 (3):220-226.

57. Parizotto N. Structural analysis of colagen fibrils after He-Ne laser photo stimulation. 2nd Congress, World Association for Laser Therapy. Kansas City. 1998.

58. Simunovic Z. Low level laser therapy of soft tissue injuries upon sport activities and traffic accidents: a multicenter, double-blind, placebocontroled clinical study on 132 patients. Pain Center-Laser Center, Locarno, Switzerland. Abstract from II Congress of the Internat. Assn for Laser and Sports Medicine, Rosario, Argentina. 200;10-12, 